\title{
Suicide candy: tracing the discourse itineraries of food risk
}

Book or Report Section

Accepted Version

Jones, R. H. (2016) Suicide candy: tracing the discourse itineraries of food risk. In: Crichton, J., Candlin, C. N. and Firkins, A. S. (eds.) Communicating risk. Palgrave Studies in Professional and Organizational Discourse. Palgrave, Balingstoke Hampshire, pp. 340-359. ISBN 9781137478771 Available at http://centaur.reading.ac.uk/58439/

It is advisable to refer to the publisher's version if you intend to cite from the work. See Guidance on citing.

Publisher: Palgrave

All outputs in CentAUR are protected by Intellectual Property Rights law, including copyright law. Copyright and IPR is retained by the creators or other copyright holders. Terms and conditions for use of this material are defined in the End User Agreement. 


\section{www.reading.ac.uk/centaur}

\section{CentAUR}

Central Archive at the University of Reading

Reading's research outputs online 
Jones, R. (2015) Suicide candy: Tracing the discourse itineraries of food risk. In C. Candlin and J. Chrichton (eds.) Communicating risk. Palgrave. 340-359.

\title{
Suicide Candy:
}

\section{Tracing the discourse itineraries of food risk}

\author{
Rodney H. Jones
}

\section{Introduction}

In a YouTube video entitled 'Suicide Candy' a poster named Sir Sebastian displays a bag of

White Rabbit Creamy Candy and declares dramatically:

I'll be the first one to admit I've eaten a lot of weird candy treats in my day. Scorpion lollypops. Mexican maggots. But never, NEVER, have I ever been in so much danger than I am with the creamy candy by White Rabbit, which has been known to actually POISON people!

Suddenly, two title slides flash up on the screen:

- Banned in 2007 for Formaldehyde contamination.

- Banned AGAIN in 2008 for Melamine contamination.

'Truthfully, ' the narrator continues,

it doesn't really look all that dangerous. It's a regular Chinese wrapping with a little white rabbit on there. But then again, I have no idea what a white rabbit means in Asia. So it could as well just mean poison!

(http://youtu.be/oRm1uG7ie2k) 
Despite the humor of this video, it highlights many important aspects of contemporary discourses of food risk: the prevalence of 'food scandals', the increasing sense that even the most innocuous seeming foodstuffs many contain 'hidden dangers', and the fact that it has become more difficult to interpret the information we are given about our food. It also highlights the unpredictable way consumers sometimes respond to information about food risks, in this case the narrator of this video appropriating the supposedly tainted candy to stage a mock suicide online.

In many ways, food risk is a very special kind of risk. It is a risk that we cannot avoid, since we must eat for our survival (Kjærnes, 2006). At the same time, we are increasingly loosing trust in the food we eat, partly because of the plethora of food scandals reported in the media, involving, for example, 'Mad Cow disease', salmonella in eggs, and horsemeat tainted hamburgers. Such incidents have deteriorated our trust not just in food producers and retailers, but also in the scientists and public officials that are supposed to keep us safe.

Nowhere is this more apparent than in China, where food scandals have been so widespread as to be regarded as major threat to the nation's standing in the world (Huang 2012). Recent scandals involve noodles tainted with calligraphy ink, fake eggs, 'sewer oil' recycled for cooking oil, soy sauce made out of human hair, and milk and milk based products (like the candy referred to above) adulterated with the industrial chemical melamine (Ross, 2012: Yan, 2012). In many of these scandals not just factory workers and farmers, but also managers, entrepreneurs, and government officials have been implicated, contributing, in the words of Yan (2012: 705) 'to a 
rapid decline of social trust... that has far-reaching social and political ramifications.'

These issues, of course, are not unique to China. In other contexts as well, inaction or obfuscation by government and and industry spokespeople, and sometimes disproportionate responses by consumers, have resulted in similar breakdowns of trust. The classic example is the British BSE scandal in which mixed messages from the government about beef infected with bovine spongiform encephalopathy caused long term damage not just to the British beef industry but also to the public's confidence in the government (Washer 2006).

Even when information about food risk is communicated in a clear and transparent fashion, however, the kinds of messages that finally reach consumers and how they actually apply these messages to decisions about buying and consuming food are notoriously unpredictable. This is because communication about food is almost never a matter of the straightforward transmission of information. Instead, every act of choosing what to eat occurs at the nexus of multiple 'itineraries' of discourse (Scollon 2008) that form complex connections among people, objects, texts, and social practices,.

\section{Risk Communication and Discourse Itineraries}

A problem with many models of risk communication is that they assume that information about risk travels along rather unproblematic pathways from experts to the media and then to the public, who apply it in a more or less rational fashion (Beacco et al., 2002). When partial or 'inaccurate' messages reach the public, or when people apply the information in unexpected ways, this is usually blamed on media 'distortions' (Suhardja, 2009) or the failure of people to 
understand the information. This 'deficit model' of risk communication (Kjærnes 2006) proposes that all we need to do is improve the quality of information reaching the public, and educate the public so they can apply that information better.

What these models ignore, first, is the fact that people rarely respond to risks based on a single stream of 'authoritative' information, but rather act on the basis of a complex mixture of many, sometimes contradictory, 'voices' coming from such sources as the mainstream media, medical professionals, the internet, and friends and family members. Second is that fact that decisions about food are rarely purely 'intellectual decisions', but are instead forms of social action which are performed with other social actors in the context of complex sets of social practices. Many of the choices we make about food are not made consciously, but rather have their source in long histories of habitual practices that have become part of the cultures of our families or our communities, practices which circulate in the form of stories, jokes, prohibitions, and prejudices that become sedimented in our 'historical bodies' (Nishida 1959). Finally, this model fails to account for the ways discourse about risk is 'resemiotized' (Iedema, 2001) as it flows 'back and forth between academic experts, regulatory practitioners, interest groups, and the general public' (Leiss, 1996, p. 86) taking on 'diffuse intertextual forms' (Beacco et al. 2012:280) along the way. What is needed, then, is a model that can trace these flows of discourse across texts, actions, practices, people, institutions, and objects, across time and space, and across multiple modes and materialities.

One approach that offers the potential to do this is mediated discourse analysis (Norris and 
Jones, 2005; Scollon, 2001). Mediated discourse analysis is centrally concerned with the relationship between discourse and action, in particular, what role discourse plays in making some actions more possible than others. One of the key challenges to understanding this is the fact that often discourse that plays a key role in amplifying or constraining a social action may be far removed from that action. A law prohibiting the manufacturer of a product from making a particular package claim (that the product, say, helps prevent heart disease) is not present in the supermarket when a customer chooses that product from the shelves. The law is manifested in the absence of the claim. The law as been resmiotized into the action of the manufacturer removing the claim, resulting in a new piece of discourse. This trajectory of discourse and action intersects, at that moment when the customer is deciding whether or not to choose the product, with the customer's own trajectory of discourse and action associated with the product, beginning perhaps with a blood test that showed high levels of cholesterol which was resemiotized into a decision to eat 'heart healthy' foods, which was later transformed into the action of choosing this product because of the original claim, an action that may have solidified into the habitual practice, until this moment in the supermarket when she notices that the discourse upon which this practice is based is no longer present. Of course, these are not the only trajectories of discourse and action that are circulating through this 'site of engagement' (Scollon 2001). Others include the trajectory of ordering, stocking and shelving the product on the part of the supermarket, the trajectory of manufacturing the product, and even trajectories of scientific research about what foods reduce the risk of heart disease.

Scollon (2008) calls these trajectories 'discourse itineraries'. The central task of mediated discourse analysis, he says, is to map these 'itineraries of relationships among text, action and the 
material world' using an analytical strategy known as nexus analysis (Scollon, 2001; Scollon \& Scollon, 2004). Nexus analysis always begins with a particular 'site of engagement', such as the moment a customer decides against purchasing a particular product in the supermarket. Any site of engagement is considered a nexus where particular people, objects, texts, and social practices come together, each with their own "histories' — the trajectories along which they traveled to reach this moment. The analytical utility of the concept of discourse itineraries, as opposed to, say, notions of 'flows of information" (see for example Beacco et al., 2012) is that it highlights how discourse might enter into a particular site of engagement in many possible forms- in the form of a 'text' such as a story or a rumour, or as a habitual practice such as the practice of only buying vegetables from a certain place, or even as an object such as a particular kind of kitchen appliance. The goal of nexus analysis is twofold: first, to understand what made this moment possible, to trace the histories of these people, objects, texts, and social practices and try to understand the conditions that led to them coming together at this particular site of engagement; and second, to understand the consequences of this nexus on human agency. To what extent does this particular momentary configuration of people, objects, texts, and social practices 'open up a window' (Scollon 2001:4) within which certain social actions are possible?

Two cautions are in order here. The first concerns the possibility of an exhaustive account of the many itineraries converging at any given moment. Even with careful ethnographic investigation, such an account is unlikely, especially since many of histories that lead up to a particular text being the way it is or a particular practice being performed the way it is are buried deep in the past and invisible to those using these texts or engaging in these practices. Such an exhaustive 
account, however, is not really the main goal. A more important goal is to understand something about these the different processes of transformation discourse undergoes as it travels along these itineraries, processes that Scollon (2008) calls processes of resemiotization. By observing these processes the analyst can uncover the basic mechanisms by which discourse about food risk gets transformed into concrete social actions and habitual social practices as it travels along multiple, intersecting discourse itineraries.

The second caution regards human agency. In one sense, nexus analysis presents a challenge to rationalist models of risk that imagine that individuals freely take actions based on the logical assessment of information. Instead it suggests that agency is distributed among multiple people, objects, texts and social practices. This should not, however, be taken as a denial of the importance of 'individual choice'. The nexus of discourse itineraries that converge on a site of engagement is not determinative of what actions social actors will take: rather it provides an environment for the negotiation of risk among these various agentive entities (see also Latour, 2007).

\section{The Site of Engagement}

The starting point for this analysis is a stretch of conversation collected during a research study on the discourse of food in Hong Kong ${ }^{1}$. As part of the study, a research assistant conducted indepth fieldwork with five families, spending a week with each family, observing meals, trips to the market, and casual conversations around food. The excerpt is part of a conversation involving

\footnotetext{
1 This research was made possible by a grant from the General Research Fund of the Hong Kong Research Grants Council Grant \# CityU 144110
} 
a middle-aged British woman who has lived in Hong Kong for over twenty years (whom I will call Janet), her 7-year-old daughter, and a friend, who was a guest for dinner. It occurred while the woman and her daughter were preparing the meal (Excerpt 1). I will use this conversation as a reference point from which to trace the discourse itineraries that converged in this moment of talk about food risk, itineraries that involve not just the history of Janet and her family, but also itineraries involving the food she is discussing, White Rabbit Candy, its involvement in various food scandals and how those scandals were responded to by government agencies, reported in the press and discussed in public. Therefore, along with this conversation, I will also use as data other interviews with Janet and her daughter, interviews with volunteers from Hong Kong and China about their experiences with White Rabbit Candy, a collection of news reports and material from blogs and internet forums.

\section{Excerpt 1: 'In the bin'}




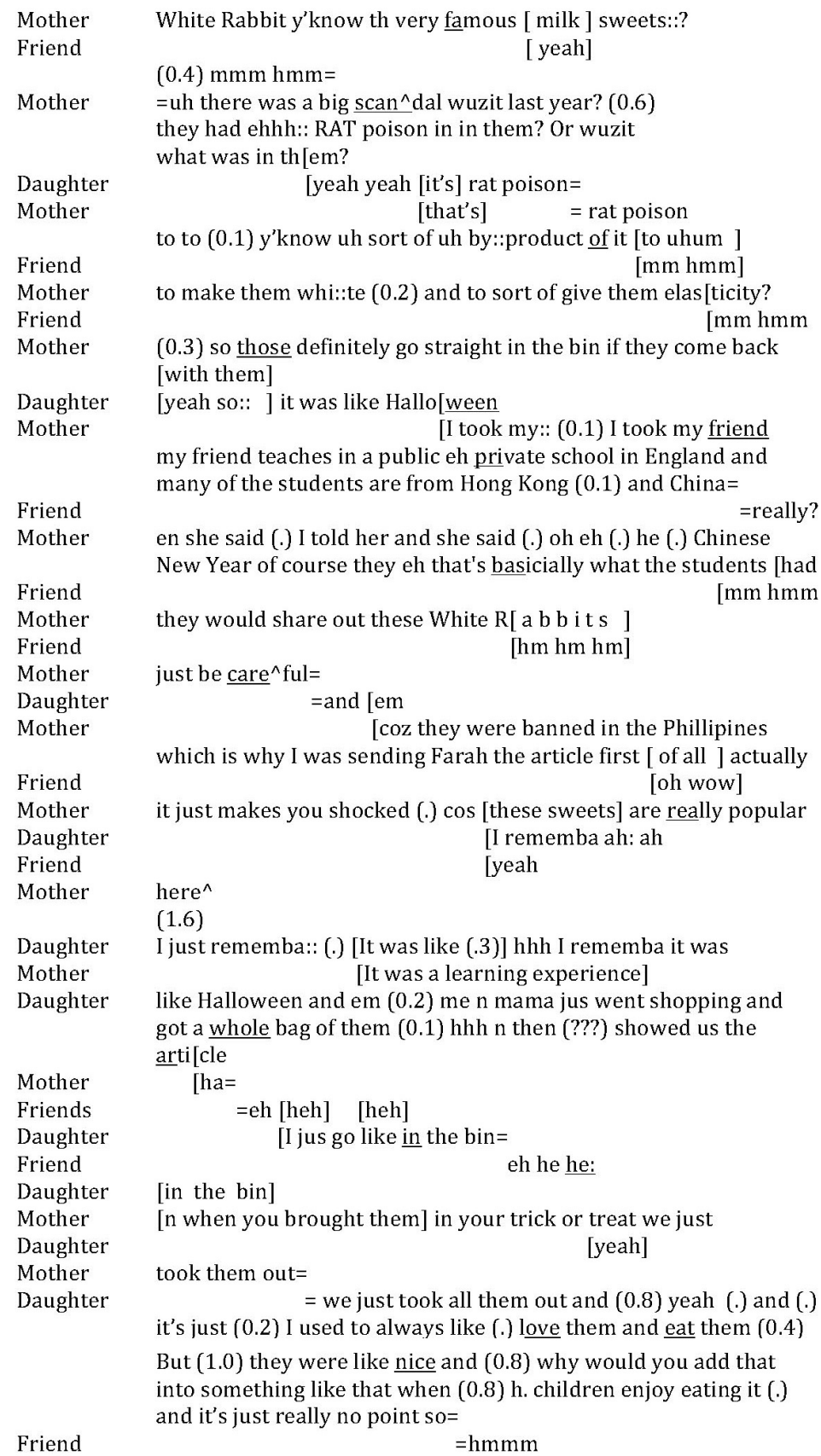

Friend

It's useful to point out at the outset that there are some inaccuracies in the information that Janet

is presenting as the basis for her decisions about this product. One inaccuracy is the statement

that 'rat poison' was found in White Rabbit Candy. Instead, the dangerous substance usually

associated with the candy is melamine, an industrial chemical. This inaccuracy might be 
something of a concern for those who take an 'information deficit' approach to risk communication or worry about how ordinary people often 'distort' information about food risks. From a mediated discourse perspective, however, our main concern is whether or not this 'distortion' has actually changed the action Janet takes (would she be more comfortable eating an industrial chemical?), as well as whether or not 'rat poison' has any particular utility in terms of what she is trying to do in this conversation.

The questions I will attempt to answer, then, have less to do with whether or not Janet's characterization of the health risks involved in eating this candy are accurate or whether or not the family's risk reduction strategy is effective, and more to do with what this conversation tells us about the processes of resemiotization that various texts and actions related to White Rabbit Candy have undergone on their pathways to this moment in Janet's kitchen.

The processes of resemiotization I will focus on are:

certification/authorization: processes through which an authoritative person or institution issues a statement about the safety or danger of a particular product, or though which a particular piece of information or practice is verified based on its association with a recognized authority. (e.g. 'They were banned in the Philippines...')

iconization/stigmatization: when a particular brand or kind of food comes to be regarded as a symbol of either quality/safety or lack of quality/danger (e,g. ' $y$ ' know the very famous 
milk sweets?').

metonymization: The process of attributing the safety or danger of a product to an ingredient or part of the product, or of attributing the safety or danger of a product to a larger class of products that it belongs to (e.g. 'It just goes to show that you can't trust ANYTHING from China anymore'). Related to this is the process of substitution, when one attribute of safety or danger is substituted for another (e.g. 'They had RAT poison in them. ').

narrativization: When certain aspects of quality/safety or danger or certain practices associated with risk are transformed into stories that circulate through social groups.

practice: when concrete social actions are submerged into the historical bodies of those who perform them, becoming 'practices' that are not just repeated but can also themselves be narrativized, authorized and iconized (e.g. in the bin!').

\section{Suicide Candy}

Food scandals involve the delegitimation of some food product that was previously regarded as safe. This process of delegitimation depends crucially on some previous process of legitimation. In the transcript above, what makes the scandal involving White Rabbit candy particularly salient is the popularity of the brand, which, as Janet remarks, formed an important part of celebrating Chinese New Year for students studying in the school her friend works at. So one important set 
of discourse itineraries that circulate through this conversation are what might be called itineraries of legitimation in which White Rabbit Candy has come to be associated with certain expectations of quality.

These itineraries can be traced back to 1943 when the ABC candy factory in Shanghai began to manufacture a milk candy named Mickey Mouse Candy. In the anti-Western political climate after the Communist victory, the candy was renamed White Rabbit, and quickly became a staple at Chinese New Year gatherings. With the reform and opening up of China beginning in the 1980's, the brand began extending its reach beyond China, first to other Asian countries and then to Europe, North America and Australia.

The rapid inconization of White Rabbit candy came as the result of the intersection of the company's itineraries of manufacturing and marketing with a number of other discourse itineraries involving the rise of China as a political and economic power. For example, in 1959, the Chinese government gave the candies as official souvenirs of the Tenth Anniversary of the People's Republic, and in 1972 President Nixon was presented with a package on the occasion of his historic visit to China. These actions constituted forms of certification, the recognition by authorities of the candy's quality and its status as a symbol of Chinese economic progress. They also demonstrate how the intersection of discourse itineraries can affect the future trajectories of these itineraries. That moment, for example, when President Nixon was handed a bag of White Rabbit Candy not only effected the trajectory of US China relations, but also the trajectory of White Rabbit as a famous brand. These implicit acts of certification were made explicit in the early 2000s when the Ministry of Commerce conferred upon White Rabbit Candy the 
designation of 'time honored brand' (中华老字号), given to brands which the government deems symbolic of Chinese quality ingenuity.

Another important itinerary White Rabbit candy intersected with in the reform and opening up period was the growth of the concept of 'quality' (suzhi) as an important cultural category. Here I am not referring just to the 'quality' of the product, but to a broader discourse that developed as China embraced modernization, urbanization and capitalism. The term subsumes notions of 'civilization', 'taste', 'etiquette', the 'quality' of consumer products, the quality of consumers themselves, and perhaps most importantly, the 'quality of the population' both bodily and spiritually (Anagnost, 2004; Jones, 2010). Interestingly, the primary intersection between White Rabbit Candy and this powerful cultural discourse itinerary occurred due to its association with milk. In the late eighties, milk began to be regarded in China as a symbol of modernity, westernization, good nutrition, and, most of all, 'quality'. Between 1980 and 2007, milk consumption in China increased from one million metric tons to 35 million metric tons (Ross, 2012). The iconization of milk was also helped along by various certifying statements from government officials, such as Premier Wen Jiabao 2006 declaration: 'My dream is for every Chinese person especially children to be able to drink $500 \mathrm{ml}$ of milk a day' ('Drink milk...' 2006).

White Rabbit candy benefited from this association of milk with the discourse of 'quality' through the process of metonymization, by which the candy came to be seen in terms of one of its 
key ingredients: whole milk powder. The company, in fact, encouraged this association though an advertising campaign in the mid 1980's that claimed that seven White Rabbit candies is equivalent to a glass of milk ('七颗大白兔奶糖等于一杯牛奶'), leading some at that time to adopt the practice of melting the candy in hot water and drinking it. Ironically it was this entanglement of the manufacturing and marketing itineraries of White Rabbit candy with those of the Chinese dairy industry that was responsible for the scandal the candy became embroiled in in 2008, and which, led Janet and her daughter (two years later) to relegate the candy to the 'bin'. Also ironic is the fact that it was the Chinese dairy industry's entanglement with the discourse of 'quality' that led to the massive demand for the milk that created the conditions for its adulteration (see below).

Of course none of these processes could have resulted in the iconization of White Rabbit candy had these itineraries not intersected with the itineraries of the everyday lives of consumers itineraries of parenting, of celebrating festivals, and of rewarding students in school- where the meaning of the brand underwent further transformations through the processes of narrativization and practice. Nearly all of the Chinese informants I talked to related fond childhood memories associated with White Rabbit Candy, often associated with Chinese New Year. One 26 year old informant recalled, 'my family bought it a lot during Chinese New Year. I used to always get it with my Lai See (red envelopes containing money)'. An older informant (aged 61), who had been a student in the 1980's, said, 'It was the best milk candy back then... sometimes we would dissolve it in our dormitories to make milk.' Another, aged 22 related a story of how her mother used the candy to make medicine more palatable: 
I was always sick and had Chinese medicine almost every day. Mother would put a White Rabbit Candy in a bowl of black Chinese medicine and say, 'good girl, after finishing this the candy is yours.' Then I'd hold my tears and finish the medicine. If I finished the medicine all at once, mother would give me the White Rabbit Candy as a reward.

Although in the conversation in Janet's kitchen there is no mention of Richard Nixon or the 'discourse of quality', or the practice of students melting pieces of White Rabbit candy in their dormitories to make milk, in a sense all of these itineraries of discourse and practice have converged to make this conversation possible. Their convergence is what makes Janet and her daughter regard the candy as 'famous', what makes them buy a bag of it in preparation for Halloween, and, of course, what heightens their horror when they find that this presumably reliable brand of candy may be, in fact, poison.

Tangled as the itinerates contributing to the legitimation or iconization of White Rabbit Candy may appear to be, those associated with its stigmatization are equally complex, implicating the brand in at least three major scandals.

The first scandal that affected White Rabbit Candy had nothing directly to do with the candy, but ended up tarnishing the name of Chinese exports in general and pre-figuring a problem with the Chinese food supply that was later to impact the candy. In 2007 several brands of pet food containing ingredients imported from China were recalled in the United States, Europe and South Africa after dogs and cats started appearing at veterinary clinics with renal failure. At first it was 
believed that the pet food contained Aminopterin, a kind of rat poison, but it was later found to contain melamine, an industrial chemical that had been added to wheat and rice gluten to increase its apparent protein levels. This scandal is important for several reasons, the most important being that it was the same widespread use of melamine by Chinese farmers and food manufacturers that led to the 2008 milk scandal that directly affected White Rabbit Candy. It was also the beginning of a growing international distrust in Chinese food products (Cai et al., 2009). Finally, the initial suspicions that the contaminant was rat poison, and the circulation of that rumor in the media, may explain why Janet identifies rat poison as the adulterant in White Rabbit Candy in the conversation above. In fact, it is not unusual to find in media reports and internet blog post about the later milk scandal melamine described as a kind of rat poison (see for example 'Watch out for candy...', 2008); it is not.

The second scandal that likely affected Janet's judgment of White Rabbit Candy involved allegations in the summer of 2007 by the Philippines Bureau of Food and Drugs that White Rabbit Candy contained formalin. Independent tests by both a Swiss company and the Singaporean government failed to find any contamination, and the manufacturer of White Rabbit claimed that the likely culprit was counterfeit White Rabbit Candy. The intersection of this scandal with Janet's conversation might be responsible for her mention of the Philippines as the country that had banned the candy, though this particular scandal did not result in any conclusive findings regarding the danger of White Rabbit Candy.

The most damaging scandal in which the candy was implicated was the 2008 Chinese milk scandal, which began when children in China started developing kidney stones at an alarming 
rate. The cause was found to be the contamination of milk powder with melamine. At least 300,000 Chinese children were affected, and at least 6 died (Ross, 2012). Although the government and dairy industry initially reported that the contamination was limited to supplies from small companies, it soon became apparent that some of the country's largest and most respected brands, including products from Sanlu, the nation's largest dairy company, had been adulterated. The revelations precipitated moves to ban Chinese milk and items containing milk (like White Rabbit Candy) throughout the world. Inside of China the scandal resulted in the firing and jailing of public officials and the execution of at least two people (Yang, 2013).

It would be impossible to untangle all of the different itineraries of discourse and action involved in this scandal. Some have suggested, for example, that government authorities may have suppressed information about the tainted milk to protect the country's image in the run up to China's hosting of the 2008 Olympics (Reporters Without Boarders, 2008). As I said above, another itinerary, the one that led milk to be associated with 'quality' in the eighties and nineties, likely created the conditions for its adulteration: under the pressure of increased consumer demand, dairy companies and the small farmers who supplied them took to watering down their milk and then 'fortifying' it with melamine to make it appear to be higher in protein (Kuehn 2009). Other itineraries of legitimation that may have contributed to the scandal include the one the resulted in a certification of the Sanlu company whereby it was granted a quality inspection and quarantine waiver, one reason products from the company went untested for so long.

Although milk powder is one of the main ingredients in White Rabbit Candy, the extent to which 
the product was actually contaminated is far from clear. Many retailers began removing the candy from their shelves before any tests had shown melamine contamination, simply because of the product's strong association with milk (Kelleher, 2008; 'Chinese sweets axed...', 2008). On September 24, the Hong Kong Centre for Food Safety released the results of tests showing that White Rabbit Candy had been found to contain melamine. Similar findings were released in Australia, Singapore and New Zealand, but did not in all cases result in recalls due to the belief that the amounts of melamine posed only a minor health risk. A news report in Singapore (Neo and Tan 2008) estimated that 'a $60 \mathrm{~kg}$ adult ... would have to eat more than 47 White Rabbit sweets ... every day over a lifetime to exceed the tolerable threshold,' (an interesting contrast to the company's previous claim that 7 White Rabbit Candies are the equivalent of one glass of milk). Nevertheless, most international distributors recalled the candy, and the company stopped exporting it for several months until 2009 when it resumed the export of candy, claiming that now it was made only with milk from Australia and New Zealand.

The apparent safety of the White Rabbit candy which was back on the market at the time of this conversation in Janet's kitchen attests to the difficulty food manufacturers have in recovering from the stigmatizing effects of food scandals, effects that are driven by processes of metonymization, narrativization, and practice.

Metonymization, as I said before, is a process by which a food product either comes to be associated with one ingredient in the product, or it becomes defined by its membership in a broader class of food products. This process is obvious along many of the itineraries associated with White Rabbit Candy, including regulatory and retail itineraries in which the candy was 
singled out for testing or even removed from shelves without testing because of its association with milk. Ironically, this was an association that the manufacturer strongly encouraged before the scandal, and was partly responsible for the candy's iconic status. A similar process can be seen in the Candy's stigmatization because of its membership in a larger class of products, specifically products from China (a form of metonymization we can refer to as generalization). Such reactions are common in the data I collected both from informants and from the internet. One writer on the Candy Blog, for example, commented:

I couldn't believe it when I saw that there is melamine in White Rabbits! I used to love these candies when I was a kid. I guess it just goes to show that you can't trust ANYTHING from China anymore.

Similarly, when asked if they ate White Rabbit Candy, several Hong Kong informants remarked that they tried to avoid eating foods imported from China altogether. One Hong Kong student said:

I try my best to avoid eating anything from China, partly because of all the bad news about the food in China, and partly because I'm in Hong Kong, and we have lots of good alternatives here.

When these Hong Kong students make such statements, it is difficult not to infer an intersection between the history of White Rabbit Candy and the Chinese melamine scandal and the itineraries of recent political developments in Hong Kong involving both concerns about political 
development of the former British colony, and growing discontent about Chinese tourists who have taken to buying large quantities of milk powder in Hong Kong for resale on the Mainland, which has led to higher prices and shortages of milk powder in the territory.

This process of generalization is also evident in Janet's household. In interviews she repeatedly told us that she avoids buying food from China, and, speaking about another product— potato chips — her daughter told an interviewer:

I wouldn't get those y'know the Chi:ne::se ones because I don't really feel comfortable with them.

From the point of view of families and individuals, though, perhaps the most potent process contributing to the stigmatization of food products is narrativization, the process by which perceived dangers are transformed into 'horror stories', which circulate through social groups. Above we saw how important personal narratives were in creating and sustaining brand loyalty to White Rabbit Candy. In the conversation in Janet's kitchen we can see how narratives can be equally powerful tools in stigmatizing products and sustaining that stigmatization over time. Narratives themselves, however, are also formed at the nexus of multiple discourse itineraries, often combining elements from actual events, hearsay, media reports, and 'cultural storylines' (myths, folktales, etc.).

The transcript above contains two narratives, both of them portraying moments of "narrow 
escape' from the dangers of eating White Rabbit Candy. The first involves Janet warning a friend of hers who teaches overseas Chinese students in the UK to 'be careful' and sending her an 'article' to authorize her concerns, taking on herself the role of issuing a kind of 'food safety warning' not unlike those issued by the governments that banned the sale of White Rabbit Candy.

A much more interesting story, however, is told by her daughter, involving how the family had bought a bag of White Rabbit Candy to give out at Halloween, only to be alerted to the danger of the candy (via what was presumably the same 'article'), and immediately responding by throwing the candy 'in the bin'. This is followed by the mother and daughter co-narrating a related account of how, when the daughter returned with her own trick or treat candy, they search through it for White Rabbit Candy and 'took them out'. What is so interesting about this story is the way it intersects with the itineraries of narratives about poisoned Halloween candy which have been circulating in the media and among parents for decades, stories which have little basis in fact, but occasionally intersect with the itineraries of actual product poisonings (such as the 1982 Tylenol poisonings - see Jones 2013), and actual cases of the adulteration of candy (like the 2008 contamination of White Rabbit Candy by melamine). In her book, Candy: A century of panic and pleasure, Samira Kawash (2013) discusses the persistence of tales of poisoned Halloween candy, tracing them back to the mid seventies when changing economic and social norms (racial integration, gender equality) precipitated an increase in societal fears about the safety of children and the danger of strangers. By linking the itinerary of the adulteration of White Rabbit candy with the persistent cultural storyline of the Halloween poisoner (whose favorite weapon is, of course, 'RAT poison'), Janet and her daughter have created a discursive artifact that is likely to 
sustain the family's stigmatization of White Rabbit Candy for some time to come.

Of course, the most powerful process of stigmatization occurs when discourse is transformed first into concrete social actions (such as deciding not to eat a particular product) and then into more durable social practices. The practice of avoiding White Rabbit Candy depends on the intersection of the candy's own scandal-marred history with itineraries of social practices that began in this family long before the safety of White Rabbit candy was called into question. One such practice is Janet's practice of paying attention to media reports about food safety. On several occasions during the study she referred to 'articles' she had read which had led her to 'ban' certain foods from her home. In a group interview with participants from other families, for example, she said:

There's one item on that table that's absolutely banned from my house that that's the Burger King crisps because I read...I read an article that said they found something terrible in them...

Practices are chains of actions that are not just repeatedly performed, but also which come to take on 'a life of their own', becoming 'objects' that can be referred to with labels or 'catch phrases'. Clearly the practice of policing the food items her children bring home and relegating unacceptable items to 'the bin' has become, for Janet and her family, a recognizable practice. In fact, the phrase 'in the bin' was one Janet used often when talking about food safety. She used the term, for example, in an earlier interview when discussing whether she let her children drink 
soda pop ('If they dare to bring home a can of Coke it goes right in the bin'), and it is also a phrase she uses at the beginning of the transcript of this interaction ('so those definitely go straight in the bin if they come back with them').

Social practices are often the end result of processes of certification/authorization, inconization/stigmatization, metonymization, and narrativization, and they can also themselves be sustained by these processes. Janet and her daughter's story about throwing the White Rabbit Candy 'in the bin', told and retold to friends and other family members, helps to sustain the practice of throwing 'dangerous' food 'in the bin' among the members of this family. In fact, by telling this story, the daughter demonstrates the extent to which she has been socialized into this practice, and the gesture she makes while uttering this phrase (see Figure 1) shows the extent to which the practice has come to be submerged into her historical body. In fact, one can imagine this gesture regularly accompanying this phrase when it is uttered in this family as a kind of icon of this social practice. So just as White Rabbit Candy has become stigmatized, the practice of avoiding it has become iconized. 
Figure 1: 'in the bin'

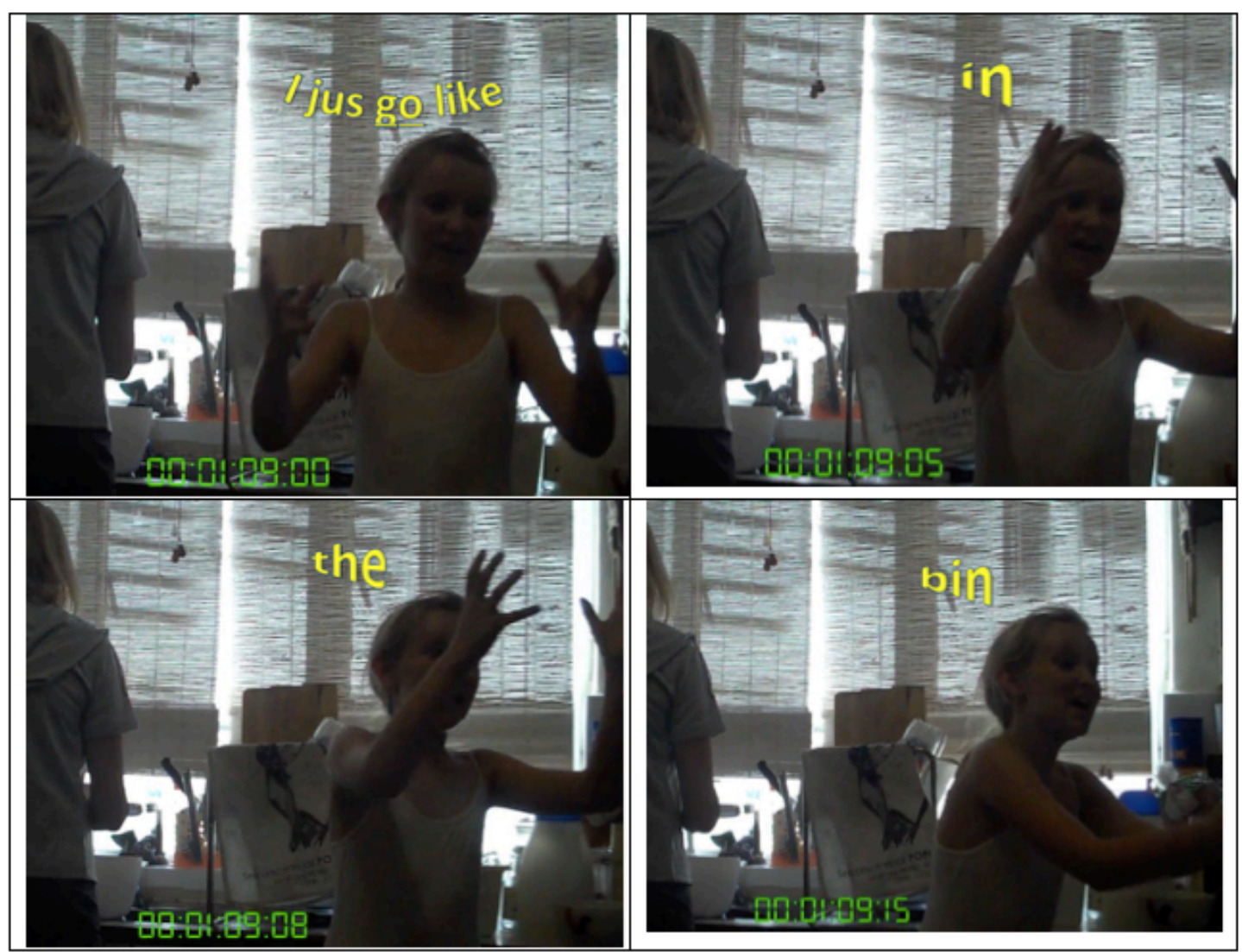

।

\section{Conclusion}

It is not hard to see that the complex intersection of discourse itineraries that result in Janet and her daughter throwing White Rabbit Candy 'in the bin' does not much resemble the model of rational decision making that many theories of health communication promote. That is not to say, however, that Janet's practices of managing food risk are not 'rational'. Rather they follow a logic much more complex than that imagined by health promoters and regulatory bodies, one which 
involves negotiating the complex interaction of discourses, practices, objects and people that come together at different sites of engagement. One might object that maybe Janet is being too harsh on White Rabbit Candy, that the business about rat poison is a bit over the top, and after all, as far as we know, White Rabbit Candy manufactured at the time of this conversation was melamine free. But such observations tell us less about the appropriateness of Janet's response and more about the challenge food companies face when they also have to negotiate the complex intertwining of multiple discourse itineraries characterised by the same processes of inconization and stigmatization.

It would also be a mistake to assume that processes of stigmatization like those cataloged here lead naturally to people avoiding certain foods. The process of generalization observed above, for example, which resulted in some participants avoiding food from China, for other participants led to a more resigned attitude. One student from Mainland China, for example, declared: 'Most of the Chinese food is kind of poisonous, and I've been exposed to it since birth, so I'm immune to it.' Similarly a poster on the Candy Blog remarked: 'Face it, what DOESN'T cause cancer these days...' Finally, there are even cases where stigmatization becomes the very reason to eat a certain food, as in the parody video I discussed at the beginning of this chapter.

The complex and contradictory discourses that coalesce around food scandals provide analysts with unique opportunities to explore how social practices around food risk develop. What this analysis highlights is how difficult it is to posit any direct relationship between 'official warnings' or media reports and people's actual behavior, since that behavior always takes place at 
the intersection of multiple itineraries of discourse and action. At the same time, it also shows how individuals operate as active agents at these sites of engagement, appropriating and mixing discourses from different itineraries and subjecting them to their own processes of iconization/stigmatization, authorization/certification, metonymization and narrativization, and how these processes lead to the transformation of these discourses into durable practices that become part of their unconscious and habituated behavior around food risk.

\section{References}

Anagonst, A. (2004) The corporeal politics of quality (Suzhi). Public Culture, 16 (2), 189-208.

Beacco, J.-C., Claudel, C., Doury, M., Petit, G., \& Reboul-Touré, S. (2002). Science in media and social discourse: new channels of communication, new linguistic forms. Discourse Studies, $4(3), 277-300$.

Cai, P., Ting, L. P., \& Pang, A. (2009). Managing a nation's image during crisis: A study of the Chinese government's image repair efforts in the "Made in China" controversy. Public Relations Review, 35(3), 213-218.

'Chinese sweets axed in milk scare' (September 24, 2008). Daily Express. Retrieved March 5, 2015, from http://www.express.co.uk/news/uk/62961/Chinese-sweets-axed-in-milk-scare.

'Drink milk everyday to benefit your health' (May 27. 2006) Xinhua. Accessed March 3, 2015 
from http://www.xinhuanet.com/xhft/20060527/wzsl.htm (in Chinese).

Huang, Y. (August 17 ,2012). China's Corrupt Food Chain. The New York Times. Retrieved January 2, 2015 from http://www.nytimes.com/2012/08/18/opinion/chinas-corrupt-foodchain.html.

Iedema, R. (2001). Resemiotization. Semiotica, 137(1-4), 23-39..

Jones, R. H. (2007). Imagined comrades and imaginary protections: Identity, community and sexual risk among men who have sex with men in China. Journal of Homosexuality, 53(3), 83115.

Jones, R. H. (2013). Health and risk communication: An applied linguistic perspective. London: Routledge.

Kelleher, S. (September 25, 2008). 'China's milk scandal has Seattle-area stores pulling candy, drinks'. The Seattle Times. Retrieved March 5, 2015, from http://www.seattletimes.com/seattlenews/chinas-milk-scandal-has-seattle-area-stores-pulling-candy-drinks/.

Kjærnes, U. (2006). Trust and distrust: Cognitive decisions or social relations? Journal of Risk Research, 9(8), 911-932. 
Kuehn, B.M. (2009). Melamine scandals highlight hazards of increasingly globalized food chain. JAMA, 301(5):473-475. doi:10.1001/jama.2009.35

Latour, B. (2007). Reassembling the social: An introduction to actor-network-theory. Oxford; New York: Oxford University Press.

Leiss, W. (1996). Three phases in the evolution of risk communication practice. Annals of the American Academy of Political and Social Science, 545: 85-94.

Nishida, K. (1959). Intelligibility and the philosophy of nothingness. Tokyo: Maruzen Co. Ltd.

Neo, C. C., \& Tan H. L. (September 22, 2008). Crying over spoilt milk. Today Online.

Retrieved on January 15, 2015 from

https://docs.google.com/viewer?url=http\%3A\%2F\%2Fwww.nuh.com.sg\%2Fwbn\%2Fslot\%2Fu1 753\%2FPatients\%2520and\%2520Visitors\%2FMedia\%2520Articles\%2FSep\%252008\%2F24th\% 2520TODAY.pdf

Norris, S., \& Jones, R. H. (2005). Discourse in action: Introducing mediated discourse analysis. London: Routledge.

Reporters Without Borders (October 2, 2008) Open letter to Margaret Chan, WHO director, about the contaminated milk powder scandal, Retrieved March 26, 2013 from http://en.rsf.org/china-open-letter-to-margaret-chan-who-02-10-2008,28791.html. 
Ross, K. (2012). Faking it: Food quality in China' IJAPS, 8: 33-54.

Scollon, R. (2001). Mediated discourse: The nexus of practice. London: Routledge.

Scollon, R. (2008). Discourse itineraries: Nine processes of resemiotization. In V. K. Bhatia, J. Flowerdew, \& R. H. Jones (Eds.), Advances in Discourse Studies (pp. 233-244). London: Routledge.

Scollon, R., \& Scollon, S. W. (2004). Nexus analysis: Discourse and the emerging internet. London: Routledge.

Suhardja, I. (2009). The Discourse of "distortion" and health and medical news reports: A genre analysis perspective. Unpublished $\mathrm{PhD}$. dissertation, Edinburgh: University of Edinburgh.

Washer, P. (2006). Representations of mad cow disease. Social Science \& Medicine, 62(2), 457466.

'Watch out for candy made in China this Halloween' (October, 2008) Harmonix Forum.

Retrieved February 25, 2015 from http://forums.harmonixmusic.com/discussion/92764/watchout-for-candy-made-in-china-this-halloween.

Yan, Y. (2012). Food Safety and Social Risk in Contemporary China. The Journal of Asian 
Studies, 71(3), 705-729.

Yang, G. (2013). Contesting food safety in the Chinese media: Between hegemony and counterhegemony. The China Quarterly, 214, 337-355. 